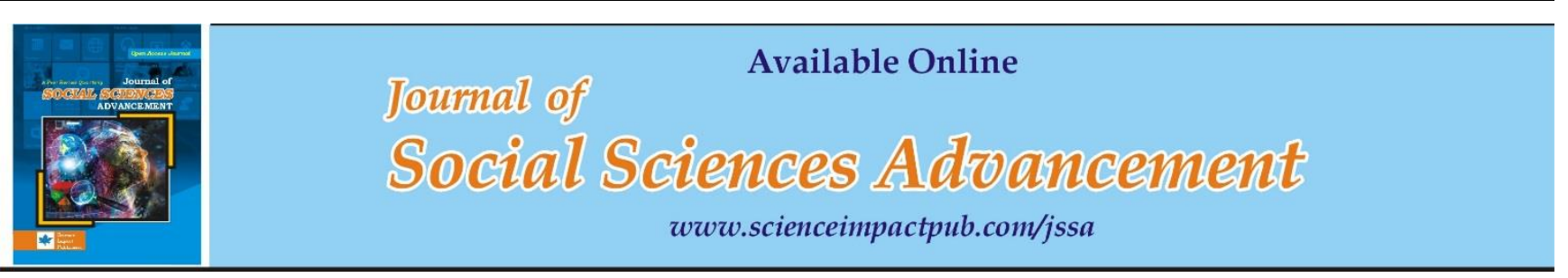

\title{
What Raises Purchase Intention of Customers? An Extension in Perspective of Nostalgic Marketing
}

\author{
Sarfaraz Ahmed Bhutto ${ }^{*}$, Saifullah Shaikh ${ }^{1}$, Hussain Amar ${ }^{2}$, Qamar Abbas Mangi', Qaisar Abbas ${ }^{3}$ \\ 1Faculty of Management Sciences, Shah Abdul Latif University Khairpur, Sindh, Pakistan \\ ${ }^{2}$ College Education Department, Sindh, Pakistan. \\ 3The Shaikh Ayaz University Shikarpur, Sindh, Pakistan
}

\section{ABSTRACT}

Emotions are considered as the real inner perception of a person. Emotions can never be ignored or completely eliminated from one's life. The point of emotion like nostalgia has immense importance in our social life and the concept of nostalgia has a great shift from organizational environment to expanding marketing world. This research aimed to determine the purchase intention as outcome of nostalgic emotions of customers. This study finds the mediating effect of attachment and attitude in between nostalgic emotions and purchase intention. The data for this research was collected from the customers of Toyota and Honda motors located in two metropolitan cities of Pakistan (i.e. Karachi and Lahore). The research has used non-probability sampling technique and cross-sectional research design was adopted. Furthermore, the adopted and modified questionnaire was used as survey instrument. The statistical outcomes were drawn from robust statistical technique, covariance-based structural equation modelling (CB-SEM). The results show that nostalgic emotion has positive and significant effect on purchase intention of customers. Moreover, mediating effect of attitude and attachment was confirmed in between nostalgic emotion and purchase intention. Consequently, this study confirmed that organizations should work on customer attitude and attachment which are the possible causes of nostalgic emotion, it may sufficiently increases customers' purchase intention.

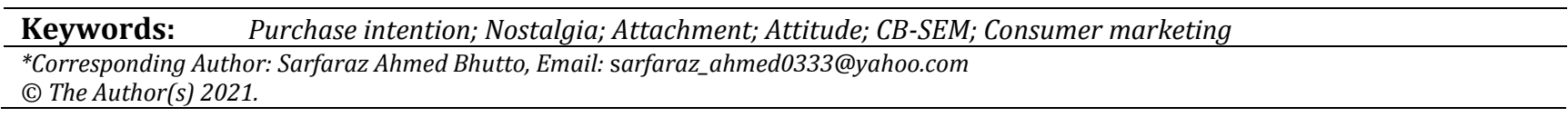

\section{INTRODUCTION}

Nostalgia can be defined as a feeling of pleasure and sometimes slight sadness at the same time as you think about things that happened in the past. Nostalgia is a fascinating topic to explore and experience. Experiential marketing has gotten a lot of attention from customers when it comes to marketing (Ju et al., 2016). The emotional aspects of customers are used in experiential marketing to advertise a product. The term "nostalgia marketing" refers to a type of marketing that is based on the concept of "experiential marketing." People's feelings and emotions form an emotional bond between the consumer and the product in this situation. People are constantly nostalgic for the excellent times they had in the past. They'll experiment with various methods to revisit those memories. Customers' nostalgic feelings can be used by marketers to make them feel more connected to their products.

Customers love it when a product or service reminds them of anything from their past. Such products or services assist customers in recalling positive memories from the past. Nostalgia marketing has been used in a variety of industries, including fashion and food. The use of nostalgia marketing in the fashion business has shown to be successful. Customers' nostalgic feelings have resulted in retro clothing in vintage style (Cervellon et al., 2012). In restaurants, where customers are more drawn to nostalgic-themed establishments, nostalgia marketing techniques have proven to be effective (Wen et al., 2019). With the debut of Pokémon Go, several studies have shown that nostalgic emotion is an important factor in recruiting players in the gaming industry (Ghazali et al., 2019; Harborth \& Pape, 2019). As a result, nostalgia marketing can be a great way to bring in new customers in the automobile industry.

Customers might form nostalgic bonds with Cars or other vehicles on their own. Car manufacturers (like Toyota and Honda) do not need to make any changes to their products in order to evoke nostalgic memories in their clients. As a result, Car producers have a chance to tap into these nostalgic feelings in order to elicit a desire to buy cars. Even though nostalgia marketing has been used in a variety of industries. Consequently, the current study aims to investigate the effects of nostalgic marketing on the car manufacturing companies like Toyota and Honda, as well as its eventual impact on customers in terms of how much or to what extent it has influenced their Purchase intentions. 


\section{LITERATURE REVIEW \& HYPOTHESES}

\section{Nostalgic Emotion}

The development of nostalgia as an emotion can occur in various ways in different people. Some fragrances can bring back memories for people just by smelling them. For others, the nostalgic feeling is evoked by the sight of oldfashioned packaged foods. It's understandable that nostalgia as an emotion varies from person to person, as does the reason for the nostalgic feeling (Holbrook \& Schindler, 2003). A person's interest in a particular event in their life is linked to nostalgia. Because of this, different brands can elicit distinct nostalgic responses in people. They can relive those experiences by shopping at stores carrying those brands. The authors Sierra and McQuitty (2007) claim that the results of a study show that people's desire to purchase vintage clothing is driven by their feelings of nostalgia (Cervellon et al., 2012). When people see old ads and photos of classic products on Pinterest's search feed, it can arouse feelings of nostalgia in them. Thus far, the results have been encouraging, with viewers increasingly turning to search engines to find more (Youn \& Jin, 2017). While creating a marketing strategy that employs nostalgic cues, the age of the target audience should be taken into account as well (Kazlauske \& Gineikiene, 2017). When it comes to nostalgic products, people of different genders and ages will have varying attitudes toward them and their associated feelings of nostalgia.

The most common way to invoke feelings of nostalgia in viewers is to depict advertisements that allude to fond memories of childhood or one's family. Additionally, the nostalgic element is more prevalent in the mature stages of the product's life cycle rather than in the beginning stages of its life cycle (Srivastava et al., 2017). According to the study, there is a connection between film destinations and viewers' emotional attachment. Tourists flock to film locations for a variety of reasons, including the nostalgic sense they get from seeing the locations where their favorite films were filmed. This rekindles fond memories for them of their time spent watching them.

A person's nostalgic feelings can be divided into two categories: personal and historical. It's clear that the gender of the individual singing the old songs has a significant impact on how the audience feels about the company's offerings. When the actual vocalist is gender mismatched with the singer used in advertising, historical nostalgia engages the audience more deeply with the items (Chou \& Singhal, 2017). The relationship between nostalgia and the food industry is put to the test by (Renko \& Bucar, 2014). It goes to show that a lot of people are shaped by the foods they ate as kids. Many countries, like Macau, use nostalgia as a tool to foster a sense of belonging and connection with the locals (Leong et al., 2015). Scola \& Gordon (2019) want to look into the topic of nostalgia in sports marketing because it is under-examined. According to (Scola \& Gordon, 2019), key themes are discovered and implemented by examining the extent to which retro marketing in relation with the history of the sports team can be linked to nostalgia.

\section{Nostalgia and Attitude}

Consumers' attitudes toward a product have improved as a result of nostalgia advertising. Advertisements like these let customers feel nostalgic and connected to a brand even if they've never used it before. According to the research of Muehling and his colleagues (2014). There is evidence that personal nostalgia affects travelers, according to the conclusions of the study. According to Italian research, people's nostalgic feelings could help the tourism business attract more customers (Phau et al., 2016). In a study, it was shown that nostalgic feelings could be a major driving force for travel (Sellick, 2004). While developing plans for nostalgia marketing, marketers must take into account the role of the consumer's sense of self-identity. Customers may form sentimental attachments to a brand if it takes this method. (Ju and colleagues, 2016) Nostalgic commercials, according to research, can influence consumer attitudes about a brand (Muehling \& Sprott, 2004).

Individualistic nostalgia and collectivistic nostalgia are the two types of consumer nostalgia discussed in the study. The aim is to develop a connection between these two nostalgias when tempered by consumer self-concept. In other words, it's a big deal. As the depth of one's own nostalgia rises, so do the attitudes and objectives of the individuals (Marchegiani \& Phau, 2010).

Using the mediating element of life satisfaction, Khoshghadam et al. (2019) assess the relationship between nostalgic music utilized in advertising in terms of brand attitude and purchase intention. The current state of one's life pleasure can be determined to be a variable in the analysis of nostalgic background music in an advertisement and their interest in the product.

Simple nostalgia is based on the belief that life was better in the past, and it portrays a desire to go back to that time period. There's also the phenomenon known as reflexive nostalgia, in which the person wonders whether the past is better than the present. Finally, interpreted nostalgia occurs when people compare the past and present while utilizing prior experiences to improve their current state of affairs (Davis, 1979). The idea behind it (Sierra \& McQuitty, 2007) is to find a link between nostalgia and the attitudes of potential customers towards the intention of buy, resulting in the development of a theory known as Social Identity Theory, which explains its procedures and complexities. The study examines the effect of three different types of cognitive users on their ability to recall positive brand encounters from the past. Heavy users, light users, and non-users are all categories within the three-tiered hierarchy. Each type's testing yielded a significantly different result, as seen in this report (Stach, 2017). 


\section{Nostalgia and Attachment}

According to the results of the study, products with nostalgic content have a higher level of sensitivity among customers. It strengthens the bond between a business and its customers (Errajaa et al., 2013). Consumers and products can form lasting bonds when nostalgic feelings are evoked, according to the findings of the study. When people buy something for the first time, it typically becomes symbolic of that experience.

The use of nostalgia marketing aids in evoking positive feelings in customers. Most customers use these items because they believe they are linked to happy memories or customary events from their past (Kessous, 2015). Nostalgia plays an important role in luring gamers to games like Pokémon Go. The presence of nostalgia influenced the way the players behaved (Ghazali et al., 2019; Harborth \& Pape, 2019). Instead of being a clear idea, ambivalent nostalgia has remained a fuzzy one.

The study's goal is to see if consumers' feelings of ambivalent nostalgia influence their loyalty to a brand and their willingness to pay a premium for it. In the study, the authors found that nostalgia has a favorable effect if it can activate an individual's cognitive thinking, acting as a mediator (Srivastava et al., 2019). As a phenomenon that influences both consumer preferences and taste patterns, nostalgia has a significant impact on both preferences and taste patterns (Holbrook, 1993). According to the findings, people's decision-making processes and nostalgic propensity are unaffected by their age.

Consumers' consumption behaviors and sensations during a purchase have been found to be influenced by their level of nostalgia. There are a number of other factors that influence behavior such as word-of-mouth, communication, and intentions (Triantafillidou \& Siomkos, 2014).

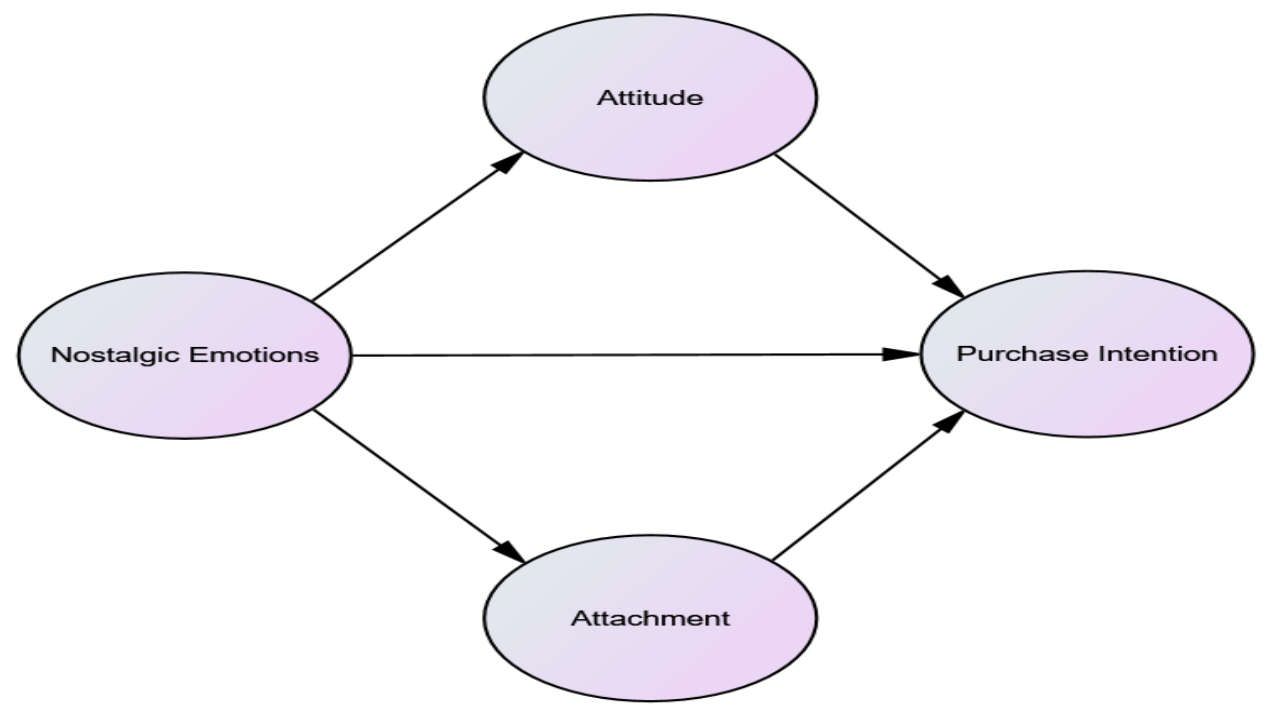

Figure 1: Research Model

Above figure shows four variables nostalgic emotions, purchase intention, attitude, and attachment. nostalgic emotions is independent variable and purchase intention is dependent variable, however attitude and attachments are mediating variables

\section{Hypotheses}

The information shown above helps to clarify the relationship between gender and nostalgic feelings, which is important for creating nostalgia marketing campaigns. (Kim \& Yim, 2018). Therefore, the following hypothesis has been derived:

\section{H1: There is a statistically significant difference in nostalgic emotion among males and females.}

The discussions above lead to the question of interaction between the variables like Nostalgic Emotion (Sierra \& McQuitty, 2007; Youn \& Jin, 2017), Attitude towards the product (Car) (Marchegiani \& Phau, 2010), Attachment towards the product (Car) (Kessous, 2015) and Purchase Intention concerning the Car (Cervellon et al., 2012). Therefore, the following hypothesis was developed:

\section{H2: Attitude has a mediating role between the nostalgic emotions and the customers' purchase intention.}

H3: Attachment has a mediating role between the nostalgic emotions and the purchase intention of the customers. 


\section{METHODOLOGY}

\section{Respondents}

Customers who buy Cars from Toyota and Honda are the subjects of this investigation. Participants must be at least 20 years old since it is usually assumed that people under the age of 20 do not have the capacity to make independent buying decisions. Moreover, Google forms were used to create questionnaires, which were then distributed across survey participants to gather responses. Sixty-two percent (62\%) of the people who responded to the survey (N=228) were women, whereas 37 percent of the people who responded were men. In addition, parents accounted for $45.6 \%$.

\section{Research Instrument}

In order to develop the questionnaire for the purpose of data collection, scales that have been validated in the previous studies have been used.

To measure variable nostalgic emotion, a 10-item scale was developed, and (Pascal et al., 2002) was being used. Four statements were selected out of the ten statements (a sample item: "Reminds me of the past.").

A seven-point Likert scale was used to measure the same. The scale developed by (Louis \& Lombart, 2010) was used to measure attachment to Cars. It is a 4-item scale, and all the statements are being used (a sample item: "I have a lot of affection for this brand").

A five-point Likert scale was used to measure the same. The scale used by (Spears \& Singh, 2004) is taken to measure attitude towards the Cars. It is a 5-item scale, and three statements were selected from it at random (a sample item: "Unpleasant / pleasant").

A five point Likert scale was used to measure the same. To measure purchase intention towards the Cars, the scale used by (Chu \& Lu, 2007) was taken. It is a 3-item scale, and all the statements were considered for the study (a sample item: "The likelihood that I would pay for online music is high"). A five-point Likert scale was used to measure the same.

\section{RESULTS AND INTERPRETATIONS}

\section{Reliability}

The Cronbach alpha value of 0.839 indicates that this sample has a good level of internal scale consistency. Cronbach alpha is greater than 0.70 , which is the upper limit for social science research (Hair et al., 2012).

\begin{tabular}{|c|c|c|c|c|}
\hline Construct & Statements & Item & Factor loadings & Cronbach's Alpha $(>0.70)$ \\
\hline \multirow{4}{*}{ Nostalgia } & Makes me think about when I was younger & N4 & 0.81 & \multirow{4}{*}{0.831} \\
\hline & Makes me feel nostalgic & N3 & 0.86 & \\
\hline & Helps me recall pleasant memories & $\mathrm{N} 2$ & 0.83 & \\
\hline & Reminds me of the past & N1 & 0.79 & \\
\hline \multirow{3}{*}{ Attachment } & Thinking about this Car brings me a lot of joy, pleasure & AC3 & 0.89 & \multirow{3}{*}{0.882} \\
\hline & I am attached to these Cars & $\mathrm{AC} 2$ & 0.93 & \\
\hline & I have a lot of affection for these Cars & $\mathrm{AC} 1$ & 0.90 & \\
\hline \multirow{3}{*}{ Attitude } & Unpleasant attitude / Pleasant attitude & AT3 & 0.92 & \multirow{3}{*}{0.783} \\
\hline & Bad attitude / Good attitude & AT2 & 0.91 & \\
\hline & Unlikeable attitude / Likeable attitude & AT1 & 0.86 & \\
\hline \multirow{3}{*}{ Purchase Intention } & In near future, I would consider purchasing Cars & PI2 & 0.84 & \multirow{3}{*}{0.767} \\
\hline & My willingness to buy Cars is very high & PI2 & 0.88 & \\
\hline & The likelihood that I would pay for Cars is high & PI1 & 0.74 & \\
\hline
\end{tabular}

\section{Structural Equation Modelling (SEM)}

Confirmatory Factor Analysis (CFA)

Table 2: Regression Weights of Measurement Model

\begin{tabular}{|c|c|c|c|c|c|c|}
\hline & & Path & Estimate & S.E. & C.R. & $P$ \\
\hline $\mathrm{N} 4$ & $<--$ & Nostalgia & 1.000 & & & \\
\hline N3 & $<---$ & Nostalgia & 0.978 & 0.710 & 13.732 & $* * *$ \\
\hline $\mathrm{N} 2$ & $<---$ & Nostalgia & 0.903 & 0.069 & 13.128 & $* * *$ \\
\hline $\mathrm{N} 1$ & $<--$ & Nostalgia & 0.865 & 0.070 & 12.367 & $* * *$ \\
\hline AC3 & $<--$ & Attachment & 1.000 & & & \\
\hline AC2 & $<---$ & Attachment & 1.006 & 0.050 & 20.216 & $* * *$ \\
\hline AC1 & $<---$ & Attachment & 1.000 & 0.053 & 18.701 & $* * *$ \\
\hline AT3 & $<---$ & Attitude & 1.000 & & & $* * *$ \\
\hline AT2 & $<---$ & Attitude & 0.983 & 0.049 & 19.972 & $* * *$ \\
\hline AT1 & $<--$ & Attitude & 0.988 & 0.056 & 17.727 & $* * *$ \\
\hline PI2 & $<---$ & Purchase Intention & 1.000 & & & \\
\hline PI2 & $<---$ & Purchase Intention & 0.979 & 0.071 & 13.816 & $* * *$ \\
\hline PI1 & $<---$ & Purchase Intention & 0.791 & 0.070 & 11.275 & $* * *$ \\
\hline
\end{tabular}




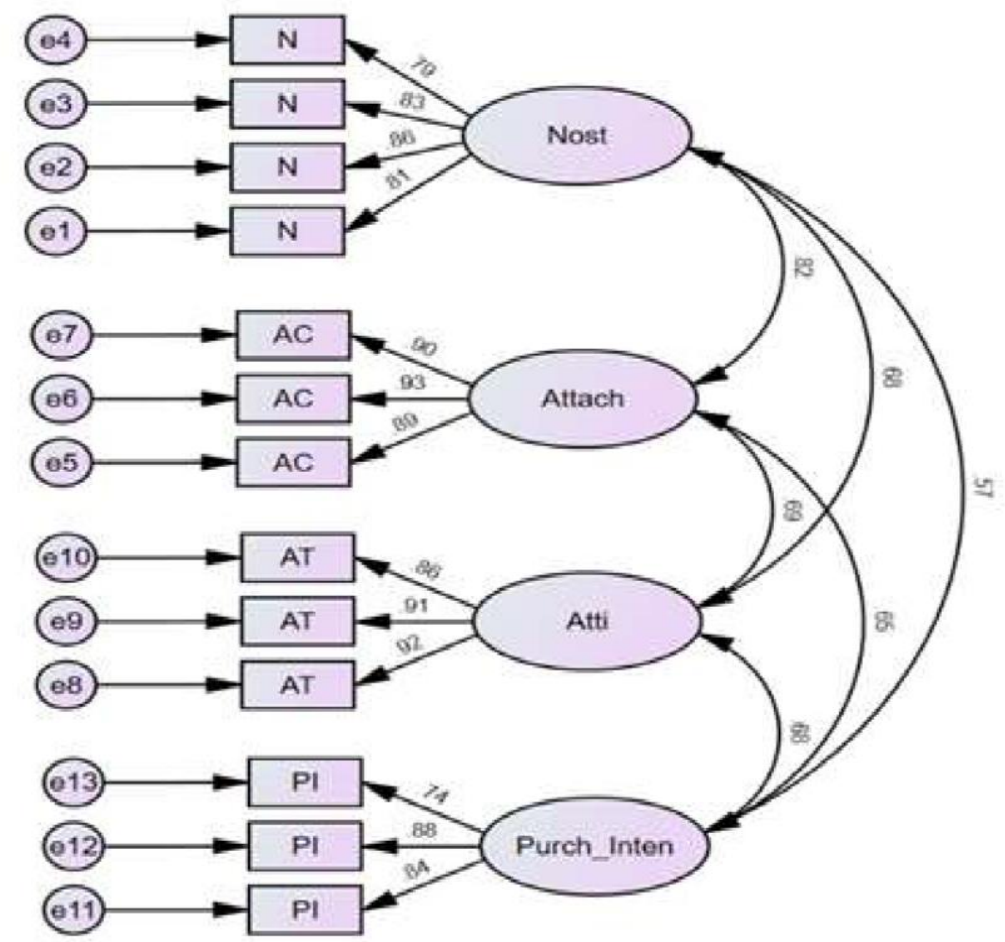

Figure 2: Confirmatory Factor Analysis

As per Table 2 and Figure 2, it can be seen that the probability value (p-value) is less than 0.05 indicating that they are within the permissible limit. The three main model fit indices in CFA for the purpose of checking the reliability of the model are stated below.

Table 3: Fitness Index Measurement

\begin{tabular}{lccc}
\hline Fit indices & Benchmark & Value & Fitness index result \\
\hline Chi-square & $\mathrm{p}<0.05$ & 0.000 & Achieved \\
RMSEA & $\mathrm{p}<0.80$ & 0.074 & Achieved \\
CFI & $\mathrm{p}>0.90$ & 0.970 & Achieved \\
TLI & $\mathrm{p}>0.90$ & 0.960 & Achieved \\
CMIN/df & $\mathrm{p}<3.0$ & 2.069 & Achieved \\
\hline
\end{tabular}

A chi-square test of independence was performed to examine the maximum likelihood statistic, $\mathrm{X} 2(59, \mathrm{~N}=228)=$ 122.056, $\mathrm{p}=0.000$. The Contrast Media Induced Nephropathy/Degrees of Freedom (CMIN/df) value is 2.069 which is less than 3 so it can be concluded that the data fits the model. The Root Mean Square Error of Approximation (RMSEA) value is less than 0.1 so no covariances needed to be drawn between the error terms. The RMSEA value is 0.074 which is also between 0.05 and 0.08 which is an indication that it is a good fit for the model.

The Confirmatory Factor Index (CFI) value is 0.970 which is between the range of 0 and 1 , and is greater than 0.95 level which indicates that it is a good fit. Additionally, with CFI, even the Tucker Lewis Index (TLI) is reported which has a value of 0.960 that ranges between 0 and 1, and is greater than 0.90 level indicating a good fit of the model. Also, as both the CFI and TLI values are less than one, we can see that CFI is greater than TLI (CFI $=0.970>$ TLI $=0.960)$.

\section{Examining Validities}

\begin{tabular}{ccccccccc}
\multicolumn{7}{c}{ Table 4: Validity Correlation between the Variables } \\
\hline Variable & C.R. & AVE & MSV & ASV & Nostalgia & Attachment & Attitude & Purchase Intention \\
\hline Nostalgia & 0.893 & 0.677 & 0.679 & 0.487 & 0.823 & & & \\
Attachment & 0.934 & 0.824 & 0.679 & 0.529 & 0.824 & 0.908 & & 0.697 \\
Attitude & 0.925 & 0.805 & 0.482 & 0.469 & 0.676 & 0.694 & 0.897 & 0.821 \\
Purchase Intention & 0.861 & 0.674 & 0.468 & 0.407 & 0.571 & 0.653 & 0.684 & \\
\hline
\end{tabular}

Construct validity is used to measure the questionnaire used in the research and their validity in interpreting the results thereof. Reliability Check conducted shows that the Composite Reliability (CR) for all the variables have a value greater than 0.7 . Construct validity can be further classified into two such as Convergent Construct Validity and Discriminant Construct Validity.

Convergent Construct Validity is a measure of the relationship between the constructs which demonstrates that all the constructs are related to one another. As per Table 4, it can be elucidated that Average Variance Extracted (AVE) 
for all the variables depicts values greater than 0.5 along with CR also being greater than AVE for all the four variables. This denotes that there exists a strong relationship within construct validity.

Discriminant Construct Validity signifies the relationship present between a construct and any unrelated measure. As per Table 4, it can be interpreted that AVE is greater than Maximum shared Squared Variance (MSV). Furthermore, it can be seen that AVE for all the variables are greater than Average shared Squared Variance (ASV).

\section{ANOVA Outcomes}

The first hypothesis was to see if there is a substantial difference in gender when it comes to nostalgic emotions. Male, female, and others were the three gender classifications. For the third category, there was no answer. The nostalgic emotion is the independent variable, while the purchase intention is the dependent variable, with Attachment and Attitude serving as mediating variables. Because the $\mathrm{p}$-value is larger than 0.05 , the ANOVA test result $(\mathrm{F}(3,192)=$ 1.207, p (0.309) > 0.05) suggested that there is no significant difference between the gender groups in terms of nostalgic emotion.

\section{Structural Equation Modelling (SEM)}

Nostalgia is investigated through the mediating factors of Attachment to the Product and Attitude towards the Product via mediation to see if Purchase Intention is influenced by it thereby, it will be possible to determine how much influence Nostalgia and Purchase Intention have on each other, which will be useful in further research. The route diagrams show the mediational link between the independent and dependent variables, as well as the beta weights or the standardized regression coefficients. They also show the correlation coefficients. In addition, bootstrapping was used to examine the statistical significance of the indirect effects, as instructed by the (Hayes \& Scharkow, 2013).

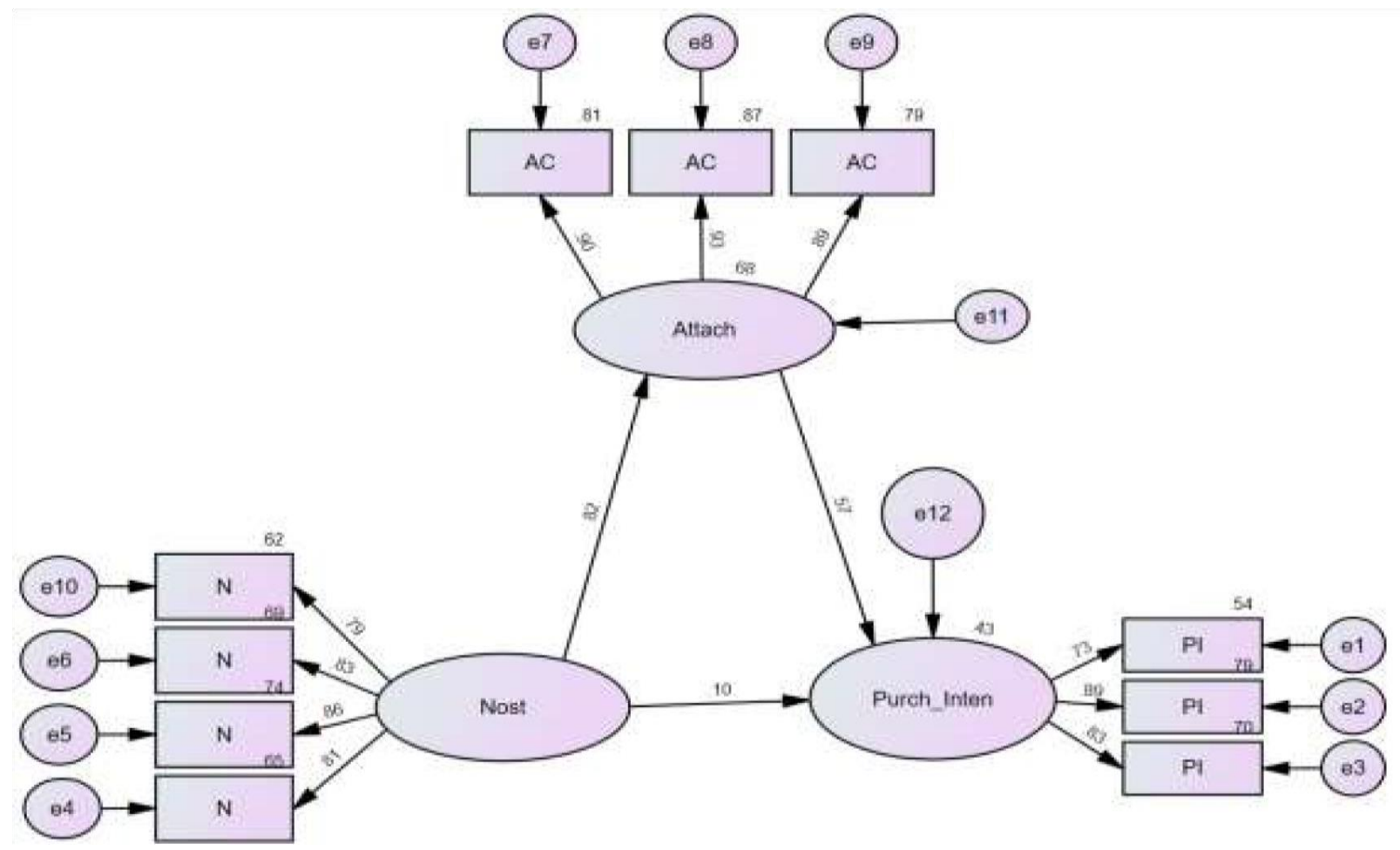

Figure 3: Mediation Model with Attachment as Mediator

Above figure shows the mediating effect of attachment between nostalgic emotions and Purchase Intention.

Table 5: Testing the Mediation Effect

\begin{tabular}{lccccc}
\hline Independent variable & Mediator & Dependent variable & Effects & $P$ & Results \\
\hline Nostalgia & Attachment & Purchase Intention & Standardized Direct Effect & 0.635 & \multirow{2}{*}{ Full Mediation } \\
Nostalgia & Attachment & Purchase Intention & Standardized Indirect Effect & 0.013 & \\
Nostalgia & Attitude & Purchase Intention & Standardized Direct Effect & 0.071 & \multirow{2}{*}{ Full Mediation } \\
Nostalgia & Attitude & Purchase Intention & Standardized Indirect Effect & 0.007 \\
\hline
\end{tabular}

Attachment to the product acted as a mediating factor in the link between Nostalgia and Purchase Intention. Results in Table 5 show that the standardized direct impact between Nostalgia and Purchase Intention has an unacceptable $\mathrm{p}$-value and is therefore statistically insignificant $(0.05, \mathrm{p}=0.635)$, as may be deduced from them. Although there is no statistically significant direct relationship between Nostalgia and Purchase Intention, there is a statistically significant indirect relationship because of the mediating variable Attachment towards the Product. 
An additional result of this study was a 95 percent confidence interval (CI) for the usual direct effect of 0.63 , which revealed that there is no mediation between the two extremes. There is mediation once the mediating variable is introduced, as shown by the bootstrapping analysis of the usual indirect impact of $0.013,95$ percent bootstrapping confidence interval: (Preacher \& Hayes, 2008). As a result, route analysis shows that Nostalgia and Purchase Intention are fully mediated by Attachment to the Product as the mediating variable.

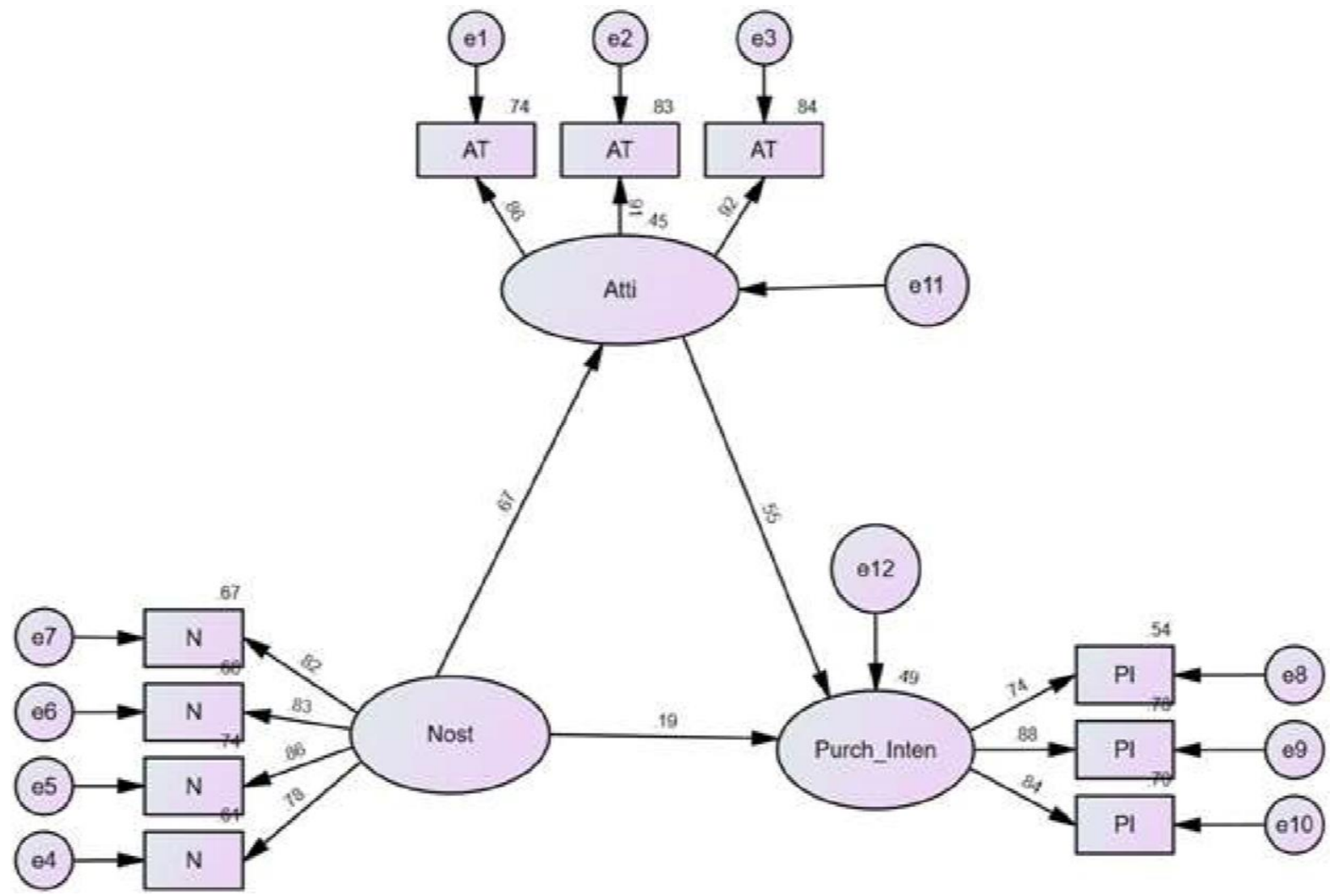

Figure 4: Mediation Model with Attitude as Mediator

Above figure shows the mediating effect of attitude between nostalgic emotions and Purchase Intention.

Attitude towards the product acted as a mediator in the link between Nostalgia and Intention to Buy. As can be deduced from Table 5, the standardized direct impact between Nostalgia and Purchase Intention has a p-value that is more than or equal to 0.05 , and so is not statistically significant. When looking at the standardized indirect impact between Nostalgia and Purchase Intention using the mediating variable Attitude towards the Brand, the result is statistically significant at $\mathrm{p}=0.007$, which is within the acceptable limit of 0.05 .

An additional result of the bootstrapping analysis shows there is no mediation in the usual direct impact of $0.071,95$ percent bootstrapping confidence intervals: There is mediation once the mediating variable is introduced, as shown by the bootstrapping analysis of the conventional indirect impact of $0.007,95 \%$ bootstrapping confidence interval: (Preacher \& Hayes, 2008). Because of this, the route analysis shows that Nostalgia and Purchase Intention are fully mediated when Attitude towards the Brand is taken into account.

\section{DISCUSSION}

According to the study's findings, there is no discernible difference in nostalgic emotions between men and women. Males and females are equally affected by nostalgic emotions. Researchers found a gender difference in nostalgic mood after conducting a study (Kazlauske \& Gineikiene, 2017; Kim \& Yim, 2018). According to the findings of this investigation, the results are different from those of earlier studies. It's possible that these discrepancies are due to variances in the study's subject matter. In addition, recent studies have been carried out in India. Lithuania and the United States have both done research on the subject in the past. As a result, automakers like Toyota and Honda may conduct gender-neutral nostalgia marketing research to better serve their diverse client base. Automobiles are a luxury item that most people can only afford on rare occasions. Of the 196 respondents who answered the survey, $38.3 \%$ said they bought a car only seldom, such as once or twice a year. Only $5.6 \%$ of respondents said they bought a car once or twice a month, on average. Automobile manufacturers may be able to devise marketing strategies to increase sales in such a scenario. This study's findings demonstrate that automobile makers should use nostalgia marketing to their advantage. The outcomes of the mediation process have shown that there is complete mediation. 
Automobile manufacturers can build a positive attitude toward their product and a strong attachment to it by using nostalgia marketing strategies. Numerous studies have already demonstrated that customers' favorable sentiments can be influenced by nostalgic feelings (Muehling et al., 2014; Phau et al., 2016). Studies have shown that people's nostalgic feelings about the past cause them to get emotionally attached to a product. Their key reason is that nostalgia makes them remember happy times from the past (Ghazali et al., 2019; Harborth \& Pape, 2019; Kessous, 2015). The desire to own an automobile is being fueled by people's favorable attitudes and emotional attachments to them. As a result, nostalgia marketing has the potential to boost auto sales. Additionally, previous studies have shown that nostalgia ads can promote a more positive mood than non-nostalgic ads (Muehling \& Sprott, 2004). According to the results of this study's questionnaire, the majority of the elderly are drawn to advertising featuring barbie dolls, Beyblade, or Yoyo. In this study, several analyses have shown that such old advertising successfully established a favorable attitude and better attachment to automobiles have proven. Since parents' memories of their childhood can be used to attract clients, marketers in this area should research that. Marketers must realize that bringing old ads back to life appeals to the elderly. This aids people in recalling happy memories from their youth. The marketer's goal should be to close the psychological gap between the customer's past and present selves (Ju et al., 2016).

\section{CONCLUSION}

Men and women had the same feelings of nostalgia, according to the findings of the study. It's also been shown that people's nostalgic feelings lead to a stronger attachment to and a more positive view of automobiles. The nostalgic feeling that builds purchase intention in the thoughts of buyers is the reason for this favorable attitude and attachment to automobiles. According to this study, nostalgia marketing is an effective technique for the automotive sector. An important research drawback is that only people from southern India participated in this study. In addition, the research looked into whether or not the automotive industry could use nostalgia marketing. Nostalgia marketing in the automotive sector has not been thoroughly examined under this topic and may be addressed in future articles. The topic of future studies could be explored further in that regard as well. It is possible to adapt a similar research pattern to new industries where nostalgia marketing has yet to be introduced or adopted, but is still in its infancy.

\section{REFERENCES}

Cervellon, M. C., Carey, L., \& Harms, T. (2012). Something old, something used: Determinants of women's purchase of vintage fashion vs second-hand fashion. International Journal of Retail and Distribution Management, 40(12), 956-974. https://doi.org/10.1108/09590551211274946

Chou, H. Y., \& Singhal, D. (2017). Nostalgia advertising and young Indian consumers: The power of old songs. Asia Pacific Management Review, 22(3), 136-145. https://doi.org/10.1016/j.apmrv.2016.11.004

Chu, C. W., \& Lu, H. P. (2007). Factors influencing online music purchase intention in Taiwan: An empirical study based on the value-intention framework. Internet Research, 17(2), 139-155. https://doi.org/10.1108/10662240710737004

Davis, F. (1979). Yearning_for_Yesterday_Nostalgia.pdf.

Errajaa, K., Partouche, J., \& Dutot, V. (2013). The co-creation process in the development of nostalgic new products. European Journal of Innovation Management, 16(4), 440-458. https://doi.org/10.1108/EJIM-11-2012-0107

Ghazali, E., Mutum, D. S., \& Woon, M. Y. (2019). Exploring player behavior and motivations to continue playing Pokémon GO. Information Technology and People, 32(3), 646-667. https://doi.org/10.1108/ITP-07-2017-0216

Hair, J. F., Sarstedt, M., Ringle, C. M., \& Mena, J. A. (2012). An assessment of the use of partial least squares structural equation modeling in marketing research. Journal of the Academy of Marketing Science, 40(3), 414-433. https://doi.org/10.1007/s11747-011-0261-6

Harborth, D., \& Pape, S. (2019). How nostalgic feelings impact Pokémon Go players-integrating childhood brand nostalgia into the technology acceptance theory. Behaviour and Information Technology, 0(0), 1-21. https://doi.org/10.1080/0144929X.2019.1662486

Hayes, A. F., \& Scharkow, M. (2013). The Relative Trustworthiness of Inferential Tests of the Indirect Effect in Statistical Mediation Analysis: Does Method Really Matter? Psychological Science, 24(10), 1918-1927. https://doi.org/10.1177/0956797613480187

Holbrook, M. B. (1993). Nostalgia and Consumption Preferences : Some Emerging Patterns of Consumer Tastes Stable URL : http://www.jstor.org/stable/2489272 REFERENCES Linked references are available on JSTOR for this article : You may need to log in to JSTOR to access the linked. 20(2), 245-256.

Holbrook, M. B., \& Schindler, R. M. (2003). Nostalgic bonding: exploring the role of nostalgia in the consumption experience. Journal of Consumer Behaviour, 3(2), 107-127. https://doi.org/10.1002/cb.127

Ju, I., Kim, J., Chang, M. J., \& Bluck, S. (2016). Nostalgic marketing, perceived self-continuity, and consumer decisions. Management Decision, 54(8), 2063-2083. https://doi.org/10.1108/MD-112015-0501 
Kazlauske, D., \& Gineikiene, J. (2017). Do you feel younger enough to choose nostalgic products? Exploring the role of age identity in nostalgic purchasing behavior. Baltic Journal of Management, 12(3), 292-306. https://doi.org/10.1108/BJM-08-2016-0185

Kessous, A. (2015). Nostalgia and brands: A sweet rather than a bitter cultural evocation of the past. Journal of Marketing Management, 31(17-18), 1899-1923. https://doi.org/10.1080/0267257X.2015.1088889

Khoshghadam, L., Kordrostami, E., \& Liu-Thompkins, Y. (2019). Experiencing nostalgia through the lens of life satisfaction. European Journal of Marketing, 53(3), 524-544. https://doi.org/10.1108/EJM-10-2017-0806

Kim, Y. K., \& Yim, M. Y. C. (2018). When nostalgia marketing backfires: Gender differences in the impact of nostalgia on youthfulness for older consumers Young. Applied Cognitive Psychology, 32(6), 815-822. https://doi.org/10.1002/acp.3459

Leong, A. M. W., Yeh, S. S., \& Chang, L. H. (2015). Nostalgic tourism in Macau the bidirectional causal relationship between destination image and experiential value. Journal of Hospitality and Tourism Technology, 6(1), 89-99. https://doi.org/10.1108/JHTT-02-2015-0010

Louis, D., \& Lombart, C. (2010). Impact of brand personality on three major relational consequences (trust, attachment, and commitment to the brand). Journal of Product and Brand Management, 19(2), 114-130. https://doi.org/10.1108/10610421011033467

Marchegiani, C., \& Phau, I. (2010). Effects of personal nostalgic response intensity on cognitions, attitudes, and intentions. Journal of Research in Interactive Marketing, 4(3), 241-256. https://doi.org/10.1108/17505931011070596

Muehling, D. D., \& Sprott, D. E. (2004). The power of reflection: An empirical examination of nostalgia advertising effects. Journal of Advertising, 33(3), 25-35. https://doi.org/10.1080/00913367.2004.10639165

Muehling, D. D., Sprott, D. E., \& Sultan, A. J. (2014). Exploring the boundaries of nostalgic advertising effects: A consideration of childhood brand exposure and attachment on consumers responses to nostalgia-themed advertisements. Journal of Advertising, 43(1), 73-84. https://doi.org/10.1080/00913367.2013.815110

Özhan, S., Altug, N., \& Deniz, E. (2018). The influence of openness to experience and nostalgia proneness on brand loyalty. Journal of Advances in Management Research, 15(4), 500-513. https://doi.org/10.1108/JAMR-112017-0106

Pascal, V. J., Sprott, D. E., \& Muehling, D. D. (2002). The influence of evoked nostalgia on consumers' responses to advertising: An exploratory study. Journal of Current Issues and Research in Advertising, 24(1), 39-47. https://doi.org/10.1080/10641734.2002.10505126

Phau, I., Quintal, V., Marchegiani, C., \& Lee, S. (2016). Looking beyond pasta and pizzas: examining personal and historical nostalgia as travel motives. International Journal of Culture, Tourism, and Hospitality Research, 10(3), 296-309. https://doi.org/10.1108/IJCTHR-07-2015-0073

Preacher, K. J., \& Hayes, A. F. (2008). Asymptotic and resampling strategies for assessing and comparing indirect effects in multiple mediator models. Behavior Research Methods, 40(3), 879- 891. https://doi.org/10.3758/BRM.40.3.879

Renko, S., \& Bucar, K. (2014). Sensing nostalgia through traditional food: An insight from Croatia. British Food Journal, 116(11), 1672-1691. https://doi.org/10.1108/BFJ-02-2014-0089

Rittichainuwat, B., \& Rattanaphinanchai, S. (2015). Applying a mixed method of quantitative and qualitative design in explaining the travel motivation of film tourists in visiting a film-shooting destination. Tourism Management, 46, 136-147. https://doi.org/10.1016/j.tourman.2014.06.005

Scola, Z., \& Gordon, B. S. (2019). Exploring retro marketing with sport marketing professionals.

Sport, Business and Management: An International Journal, 9(3), 284-300. https://doi.org/10.1108/SBM-06-20180046

Sellick, M. C. (2004). Discovery, connection, nostalgia: Key travel motives within the senior market. Journal of Travel and Tourism Marketing, 17(1), 55-71. https://doi.org/10.1300/J073v17n01_04

Sierra, J. J., \& McQuitty, S. (2007). Attitudes and emotions as determinants of nostalgia purchases: An application of social identity theory. Journal of Marketing Theory and Practice, 15(2), 99-112. https://doi.org/10.2753/MTP1069-6679150201

Spears, N., \& Singh, S. N. (2004). Measuring attitude toward the brand and purchase intentions. Journal of Current Issues and Research in Advertising, 26(2), 53-66. https://doi.org/10.1080/10641734.2004.10505164

Srivastava, E., Maheswarappa, S. S., \& Sivakumaran, B. (2017). Nostalgic advertising in India: a content analysis of Indian TV advertisements. Asia Pacific Journal of Marketing and Logistics, 29(1), 47-69. https://doi.org/10.1108/APJML-10-2015-0152

Srivastava, E., Maheswarappa, S. S., \& Sivakumaran, B. (2019). Nostalgic advertising: managing ambivalence to make it work. Marketing Intelligence and Planning, 37(3), 284-297. https://doi.org/10.1108/MIP-04-2018-0127

Stach, J. (2017). How memorable experiences influence brand preference. Qualitative Market Research, 20(4), 394415. https://doi.org/10.1108/QMR-03-2016-0023 
Triantafillidou, A., \& Siomkos, G. (2014). Consumption experience outcomes: Satisfaction, nostalgia intensity, wordof-mouth communication and behavioural intentions. Journal of Consumer Marketing, 31(6-7), 526-540. https://doi.org/10.1108/JCM-05-2014-0982

Wen, T., Qin, T., \& Liu, R. R. (2019). The impact of nostalgic emotion on brand trust and brand attachment: An empirical study from China. Asia Pacific Journal of Marketing and Logistics, 31(4), 1118-1137. https://doi.org/10.1108/APJML-09-2018-0390

Youn, S., \& Jin, S. V. (2017). Reconnecting with the past in social media: The moderating role of social influence in nostalgia marketing on Pinterest. Journal of Consumer Behaviour, 16(6), 565-576. https://doi.org/10.1002/cb.1655

Zhao, G., Li, W., Teng, L., \& Lu, T. (2014). Moderating Role of Consumer Self-Concept on the Effectiveness of Two Nostalgia Appeals. Journal of Promotion Management, 20(1), 1-19. https://doi.org/10.1080/10496491.2013.829157

Publisher's note: Science Impact Publishers remain neutral with regard to jurisdictional claims in published maps and institutional affiliations.

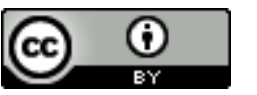
Open Access This article is licensed under a Creative Commons Attribution 4.0 International License, which permits use, sharing adaptation, distribution and reproduction in any medium or format, as long as you give appropriate credit to the original author(s) and the source, provide a link to the Creative Commons license and indicate if changes were made. The images or other third-party material in this article are included in the article's Creative Commons license, unless indicated otherwise in a credit line to the material. If material is not included in the article's Creative Commons license and your intended use is not permitted by statutory regulation or exceeds the permitted use, you will need to obtain permission directly from the copyright holder. To view a copy of this license, visit https://creativecommons.org/licenses/by/4.0/.

(C) The Author(s) 2021 